\title{
A clinical study of feto-maternal outcome in pregnancies with oligohydramnios
}

\author{
Radhamani S.*, Babitha
}

Department of Obstetrics and Gynecology, Mysore Medical College and Research Institute, Mysore, Karnataka, India

Received: 18 January 2017

Accepted: 06 February 2017

\author{
*Correspondence: \\ Dr. Radhamani S, \\ E-mail: radhamaniobg@gmail.com
}

Copyright: $(\odot$ the author(s), publisher and licensee Medip Academy. This is an open-access article distributed under the terms of the Creative Commons Attribution Non-Commercial License, which permits unrestricted non-commercial use, distribution, and reproduction in any medium, provided the original work is properly cited.

\section{ABSTRACT}

Background: The amniotic fluid that surrounds the fetus serves several roles during pregnancy. Oligohydramnios is diagnosed when ultrasonographically the AFI is less than $5 \mathrm{~cm} / 5$ th percentile. It affects $3-5 \%$ of all pregnancies. Assessment of amniotic fluid volume is a helpful tool in determining who is at risk for potentially adverse obstetric and perinatal outcome.

Methods: Pregnant women with oligohydramnios reporting to Cheluvamba Hospital, attached to Mysore Medical College and Research Institute, Mysore from December 2012- June 2014 were included in the clinical study of maternal and fetal outcome. All singleton, non-anomalous, low risk pregnancies with AFI $\leq 5 \mathrm{~cm}$ with intact membranes and gestational age between 28-42 weeks were included in the study. Various outcomes such as mode of delivery, meconium staining, Apgar at 1 and 5 minutes, birth weight and NICU admissions were assessed.

Results: A total of 130 cases of isolated oligohydramnios were assessed. $55.4 \%$ had vaginal delivery. $13.8 \%$ underwent elective LSCS and 30.8\% had emergency LSCS. $18.5 \%$ had meconium stained liquor, $4.6 \%$ babies had APGAR of $<7$ at 5 minutes. $17.7 \%$ had birth weight of $<2.5 \mathrm{~kg}$ and $6.9 \%$ of babies required NICU admission.

Conclusions: The present study was conducted to know the feto-maternal outcome in pregnancies with oligohydramnios. The study showed that isolated oligohydramnios had no adverse maternal or perinatal outcome.

Keywords: Abnormal liquor volume, Isolated oligohydramnios

\section{INTRODUCTION}

The amniotic fluid that surrounds the fetus serves several roles during pregnancy. It creates space for musculoskeletal development, promotes normal fetal lung development and helps to avert compression of the umbilical cord. ${ }^{1}$ Amniotic fluid volume is the sum of inflow and outflow of fluid into amniotic space and as such reflects fetal fluid balance. The amniotic fluid volume at each week of pregnancy is variable. It increases from $20 \mathrm{ml}$ at 10 weeks to $770 \mathrm{ml}$ at 28 weeks, remains at a steady state till 39 weeks after which it decreases dramatically. The average amniotic fluid volume in $3^{\text {rd }}$ trimester is 700-800 ml. Clinical assessment of amniotic fluid volume including bimanual palpation, symphysiofundal height is unreliable. Diagnosis is usually done by ultrasound. Definition of increased or decreased amniotic fluid volume are based on sonographic criteria. ${ }^{2}$ Oligohydramnios is diagnosed when ultrasonographically the AFI is $\leq 5 \mathrm{~cm}$ or $5^{\text {th }}$ percentile, or a single deepest pocket of $<2 \mathrm{~cm}$. It affects $3-5 \%$ of the pregnancies. ${ }^{2}$ It is associated with high risk adverse perinatal outcome like fetal distress, meconium staining, low APGAR and neonatal resuscitation, NICU admission, however it is a poor predictor. It is often used as an indicator for delivery. This assessment is a helpful tool in determining the risk of potentially adverse obstetric and perinatal outcome. The objective of the study is to examine the obstetric and perinatal outcome in pregnancies with oligohydramnios. 


\section{METHODS}

The present study was conducted in the Department of Obstetrics and Gynecology, Cheluvamba Hospital, MMCRI, Mysore, during the period of December 2012June 2014. Data was collected using a pretested proforma meeting the objectives of the study by convenience sampling method.

The patients who were diagnosed to have oligohydramnios, of gestational age 28-42 weeks were included in the study. Selection of cases were based on detailed history like duration of amenorrhea, fetal movements, past obstetric history, medical history regarding hypertension, diabetes mellitus and renal disease were recorded.

On clinical examination presence of anemia, pedal edema, blood pressure was recorded. Routine examination of cardiovascular and respiratory system was made. Per abdomen and per vaginal examination were done. All cases were subjected to routine blood investigations like blood grouping, $\mathrm{Rh}$ typing, HIV, HbsAg, VDRL, GTT, urine routine and microscopy. Detailed USG examination was done and AFI was measured using Phelan's four quadrant ultrasound technique $^{14}$. The largest vertical pocket free of fetal parts and umbilical cord loops in each quadrant was measured and AFI was taken as a sum of 4 quadrants in $\mathrm{cm}$. AFI between $5-24 \mathrm{~cm}$ is normal. AFI $\leq 5 \mathrm{~cm}$ is considered oligohydramnios. A total of 130 cases of isolated oligohydramnios were studied during this period.

\section{The following outcomes were assessed}

- Mode of delivery

- Meconium staining

- Apgar at 1 and 5 minutes

- Birth weight

- $\quad$ NICU admissions

\section{Eligibility criteria}

\section{Inclusion criteria}

- $\quad$ Pregnant women with gestational age between 28-42 weeks with intact membranes.

- $\mathrm{AFI} \leq 5 \mathrm{~cm}$ as determined by ultrasonography.

- Singleton pregnancy.

\section{Exclusion criteria}

- $\quad$ Premature rupture of membranes.

- Post term pregnancies.

- High risk pregnancies- like diabetes mellitus, hypertension, renal disease, pre-eclampsia etc.

- Congenital anomalies of the fetus.

\section{RESULTS}

Table 1 shows the gestational age at the time of diagnosis of isolated oligohydramnios. Most of the patient (54.6\%) were between 37-40 years of age.

Table 1: Period of gestation.

\begin{tabular}{|c|c|c|c|}
\hline & Oligohydramnios \\
\hline \multirow{6}{*}{ POG } & \multirow{2}{*}{$<37$} & Count & 8 \\
\hline & & $\%$ of GRP & $6.15 \%$ \\
\hline & \multirow{2}{*}{$37-40$} & Count & 71 \\
\hline & & $\%$ of GRP & $54.6 \%$ \\
\hline & \multirow{2}{*}{$41-42$} & Count & 51 \\
\hline & & $\%$ of GRP & $39.2 \%$ \\
\hline \multirow{2}{*}{\multicolumn{2}{|c|}{ Total }} & Count & 130 \\
\hline & & $\%$ of GRP & $100.0 \%$ \\
\hline
\end{tabular}

Table 2: Mode of delivery.

\begin{tabular}{|l|l|l|l|}
\hline \multirow{2}{*}{} & \multirow{2}{*}{ VD } & Count & Oligohydramnios \\
\hline \multirow{2}{*}{ MOD } & \multirow{2}{*}{ Em LSCS } & $\begin{array}{l}\text { \%of GRP } \\
\text { Count }\end{array}$ & $55.4 \%$ \\
\hline & $\begin{array}{l}\text { \% of GRP } \\
\text { El }\end{array}$ & $30.8 \%$ \\
\hline \multirow{2}{*}{ Total } & \multirow{2}{*}{ El LSCS } & Count & 18 \\
\hline & & \% of GRP & $13.8 \%$ \\
\hline & & Count & 130 \\
\hline
\end{tabular}

The table 2 shows the mode of delivery in cases of isolated oligohydramnios. $55.4 \%$ had a normal vaginal delivery, $30.8 \%$ underwent emergency LSCS and $13.8 \%$ underwent elective LSCS.

Table 3: Characteristic of liquor.

\begin{tabular}{|c|c|c|c|}
\hline & & & Oligohydramnios \\
\hline \multirow{4}{*}{ Liquor } & \multirow{2}{*}{$\mathrm{C}$} & Count & 106 \\
\hline & & $\%$ of GRP & $81.5 \%$ \\
\hline & \multirow{2}{*}{ M } & Count & 24 \\
\hline & & $\%$ of GRP & $18.5 \%$ \\
\hline \multirow{2}{*}{\multicolumn{2}{|c|}{ Total }} & Count & 130 \\
\hline & & $\%$ of GRP & $100.0 \%$ \\
\hline
\end{tabular}

Table 3 depicts that majority of cases $(81.5 \%)$ had normal colour of liquor and only $18.5 \%$ had meconium staining.

Table 4: APGAR scores.

\begin{tabular}{|c|c|c|c|c|}
\hline & & & $\begin{array}{l}\text { At } 1 \\
\text { minute }\end{array}$ & $\begin{array}{l}\text { At } 5 \\
\text { minutes }\end{array}$ \\
\hline \multirow{4}{*}{ APGAR } & \multirow{2}{*}{$<7$} & Count & 31 & 6 \\
\hline & & $\%$ of GRP & $23.8 \%$ & $4.6 \%$ \\
\hline & \multirow{2}{*}{$>7$} & Count & 99 & 124 \\
\hline & & $\%$ of GRP & $63.3 \%$ & $95.4 \%$ \\
\hline \multirow{2}{*}{\multicolumn{2}{|c|}{ Total }} & Count & 130 & 130 \\
\hline & & $\%$ of GRP & $100.0 \%$ & $100 \%$ \\
\hline
\end{tabular}


APGAR scores of babies born. $95.4 \%$ of babies had an APGAR of $>7$ at 5 minutes of birth.

Table 5: Birth weight.

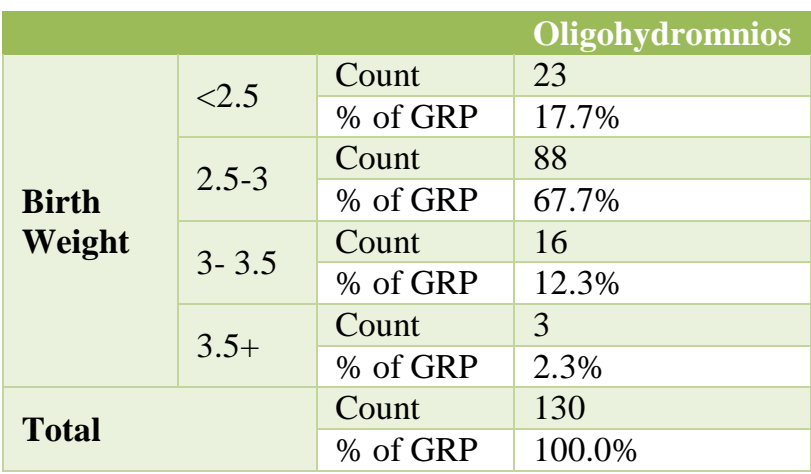

Table 5 shows the birth weight in these cases. Majority of the babies $(67.7 \%)$ had a birth weight between $2.5-3 \mathrm{kgs}$.

\section{DISCUSSION}

In this clinical study, 130 women with isolated oligohydramnios, with gestational age 28-42 weeks were analyzed for maternal and perinatal outcome. Maximum no of patients $(66.9 \%)$ belonged to $20-24$ years' age group and oligohydramnios was more common in primigravidas $(66.2 \%))^{3,4}$

Table 6: Maternal and perinatal outcome in oligohydramnios.

\begin{tabular}{|l|l|}
\hline Outcome & Oligohydramnios $(\mathbf{n = 1 3 0})$ \\
\hline Induction of labour & $75.5 \%$ \\
\hline Vaginal delivery & $55.4 \%$ \\
\hline $\begin{array}{l}\text { LSCS } \\
\text { Emergency }\end{array}$ & $30.8 \%$ \\
Elective & $13.8 \%$ \\
\hline $\begin{array}{l}\text { Meconium stained } \\
\text { liquor }\end{array}$ & $18.5 \%$ \\
\hline Preterm delivery & $12.3 \%$ \\
\hline Apgar $<7$ at 5 min & $4.6 \%$ \\
\hline Birth weight $<2.5 \mathrm{~kg}$ & $17.75 \%$ \\
\hline NICU admission & $6.9 \%$ \\
\hline PNM & $3.07 \%$ \\
\hline
\end{tabular}

Table 7: Comparative study for induction of labour in oligohydramnios.

\begin{tabular}{|l|l|l|l|}
\hline & $\begin{array}{l}\text { Bachhav et } \\
\text { al }^{5}\end{array}$ & $\begin{array}{l}\text { Jaindal et } \\
\text { al }^{10}\end{array}$ & $\begin{array}{l}\text { Present } \\
\text { Study }\end{array}$ \\
\hline $\begin{array}{l}\text { Percentage of } \\
\text { Induction }\end{array}$ & 86 & 58 & 75 \\
\hline
\end{tabular}

Induction rate in the present study was high, $75 \%$, out of which $26.5 \%$ underwent emergency LSCS. Similar high rates of induction were seen in other studies as well. In a study by Bachhav et al, labour was induced in $86 \%$ of women of which $61 \%$ underwent LSCS. $^{5}$ In a study by
Jindal et al, $58 \%$ were induced out of which $42 \%$ underwent LSCS. ${ }^{6-9}$

In present study, high rate of induction of labour was performed among women with isolated oligohydramnios. ${ }^{10-12}$ This is similar to that reported by others, where $50 \%$ of low risk women with reduced amniotic fluid volume underwent induction of labour. ${ }^{13}$

Table 8: Comparative study for indications for emergency LSCS in oligohydramnios.

\begin{tabular}{|l|l|}
\hline & Foetal distress (\%) \\
\hline Umber A et $\mathrm{al}^{9}$ & 32 \\
\hline${\text { Bachhav et } \mathrm{al}^{5}}^{5}$ & 24 \\
\hline${\text { Jandial C et } \mathrm{al}^{10}}^{10}$ & 42 \\
\hline Nazlima et $\mathrm{al}^{11}$ & 58 \\
\hline Present Study & 31 \\
\hline
\end{tabular}

In the present study, fetal distress in the form of FHR variability, meconium stained liquor was the indication for emergency LSCS in $31 \%$ of cases. Similar observations were made by Umber et al (32\%), Bachhav et al $(24 \%)$ and Jindal et al $(42 \%))^{5,9,11}$ Whereas Nazlima et al observed that $58 \%$ of emergency LSCS was for fetal distress.

Table 9: Comparative study for perinatal outcome in oligohydramnios.

\begin{tabular}{|l|l|l|l|}
\hline & $\begin{array}{l}\text { Nazlima et } \\
\text { al }^{11}\end{array}$ & $\begin{array}{l}\text { Umber et } \\
\text { al }^{9}\end{array}$ & $\begin{array}{l}\text { Present } \\
\text { study }\end{array}$ \\
\hline $\begin{array}{l}\text { APGAR }<7 \\
\text { at 5 Min }\end{array}$ & $26.9 \%$ & $6 \%$ & $4.6 \%$ \\
\hline$<2.5 \mathrm{~kg}$ & $65.3 \%$ & $36 \%$ & $17.7 \%$ \\
\hline$>3.5 \mathrm{~kg}$ & - & $2.7 \%$ & $2.3 \%$ \\
\hline $\begin{array}{l}\text { NICU } \\
\text { admission }\end{array}$ & $19.2 \%$ & $7 \%$ & $6.9 \%$ \\
\hline PNM & $2.4 \%$ & - & $3.07 \%$ \\
\hline
\end{tabular}

An APGAR score of $<7$ was seen in $26.9 \%$ of babies in Nazlima et al, $12 \%$ of babies by Jindal et al. in the present study only $4.6 \%$ of babies had APGAR $<7$ at 5 minutes similar to Umber et al. ${ }^{5,9,11}$

$17.7 \%$ of the babies were less than $2.5 \mathrm{~kg}$ compared to $64 \%$ by Bachhav et al and $65.3 \%$ by Nazlima et al. $2.3 \%$ were more than $3.5 \mathrm{~kg}$, comparable to Umber et al $(2.7 \%) .^{5,11}$

NICU admission was seen in $6.9 \%$ of babies, comparable to Umber et al $(8.1 \%)$. Perinatal mortality was $3.07 \%$ similar to that found by Nazlima et al $(2.4 \%) .{ }^{9,11}$

\section{CONCLUSION}

The study showed that isolated oligohydramnios had no adverse maternal and perinatal outcome. 


\section{ACKNOWLEDGEMENTS}

Authors express the sincere and deep sense of gratitude to Dr HC Lokeshchandra, professor of department of Obstetrics and Gynecology, Mysore Medical College and Research Institute, Mysore for the valuable guidance, expert advice, and constant encouragement. Authors also extend a sincere thanks to all patients who have helped throughout the study.

Funding: No funding sources Conflict of interest: None declared

Ethical approval: The study was approved by the Institutional Ethics Committee

\section{REFERENCES}

1. Cunningham, leveno, Bloom, Hauth, Rouse, Spong. Williams Obstetrics, $23^{\text {rd }}$ ed. USA:McGraw-Hill; 2010: 490- 499.

2. James DK, Steer PJ, Weiner CP, Gonik B. High risk pregnancy: management options. $4^{\text {th }}$ ed. $2007: 197-$ 207.

3. Gabbe SG, Niebyl JR, Galan HL, Jauniaux ERM, Landon MB, Simpson JL et al. Obstetrics, Normal and Problem Pregnancies. $6^{\text {th }}$ ed. 2016:759-9.

4. Gita G, Shweth P, Arvind L, Shashi K. A prospective clinical study of feto-maternal outcome of pregnancies with abnormal liquor volume. J Obstet Gynaecol India. 2011;61(6):652-5.

5. Bachhav AA, Waiker M. Low amniotic index at term as a predictor of adverse perinatal outcome. J Obstet Gynaecol India. 2014;64(2):120-3.

6. Jun Z, James T, Susan M, Mark AK, William FR. Isolated Oligohydromnios is not associated with adverse perinatal outcomes. DJOG. 2004;111:220-5.
7. Ulkar K, Ozdemir IA. The Relation of Intrapartum Amniotic Fluid Index to Perinatal Outcomes. Kafkas J Med Sci. 2011;1(1):1-7

8. Desai P, Patel P, Gupta A. Decreased amniotic fluid index in low risk pregnancy: any significance. J Obstet Gynaecol India. 2004;54(5):464-6.

9. Umber A. Perinatal outcome in pregnancies complicated by isolated Oligohydromnios at term. Annals. 2009;15(1):35-7.

10. Jandial C, Gupta S, Sharma S, Gupta M. Perinatal Outcome After Antepartum diagnosis of oligohydromnios at or Beyond 34 weeks of Gestation. JK science. 2007;9(4):213-4.

11. Nazlima N, Fathima B. Oligohydromnios at third trimester and perinatal outcome. Bangladesh J Med sci. 2012;11(1):33-6.

12. Casey BM, McIntire DD, Bloom SL, Lucas MJ, Santos R, Twickler DM et al. Pregnancy outcome after diagnosis of Oligohydromnios. Am J Obstet Gynecol. 2000;182(4):902-12.

13. Anna Locatelli, Patrizia Vergani, Laura Toso, Maria Verderio, John C Pezzullo, Alessandro Ghidini. Perinatal outcome associated with oligohydromnios in uncomplicated term pregnancies. Arch Gynecol Obstet. 2004;269(2):132-3.

14. Phelan JP, Smith CV, Broussad P, Small M. Amniotic fluid volume assessment with four quadrant technique at 36-42 weeks' gestation. J Repord Med. 1987;3(2):540-2.

Cite this article as: Radhamani S, Babitha. A clinical study of feto-maternal outcome in pregnancies with oligohydramnios. Int $\mathbf{J}$ Reprod Contracept Obstet Gynecol 2017;6:868-71. 